Western North American Naturalist 69(2), (C) 2009, pp. 215-222

\title{
GENETICS OF ALLOPATRIC POPULATIONS OF THE MONTANE VOLE (MICROTUS MONTANUS) AND MOGOLLON VOLE (MICROTUS MOGOLLONENSIS) IN THE AMERICAN SOUTHWEST
}

\author{
Jennifer K. Frey ${ }^{1,2}$
}

\begin{abstract}
Variation at 21 allozyme loci and 10 restriction enzymes within the mitochondrial DNA control region was assessed among 3 allopatric populations of montane vole (Microtus montanus) in the American Southwest. Among populations of M. montanus, the population from the White Mountains, Arizona, was most genetically divergent. Genetic and biogeographic evidence supported recognition of the White Mountains population as a distinct subspecies, M. m. arizonensis. Results also supported recognition of the Mogollon vole (Microtus mogollonensis) as distinct from the Mexican vole (Microtus mexicanus).
\end{abstract}

Key words: genetic variation, Microtus montanus, montane vole, Microtus mogollonensis, Microtus mexicanus, allozyme, mtDNA, White Mountains, Jemez Mountains, Rocky Mountains, Arizona, New Mexico.

The montane vole (Microtus montanus) is widely distributed throughout western North America, where it generally inhabits moist, grassy situations within coniferous forest zones (Anderson 1959, Hall 1981). Microtus montanus reaches its southern range limits in the southwestern USA where it has a disjunct distribution in isolated mountain ranges (Fig. 1). A large and relatively continuous distribution occurs throughout the southern Rocky Mountains in Colorado (Armstrong 1972). This population extends southward into the San Juan Range of the southern Rocky Mountains in northern New Mexico (Findley et al. 1975). Southward, the species occurs in 2 isolated mountain ranges including the Jemez Mountains in north central New Mexico and the White Mountains in east central Arizona and adjacent areas in west central New Mexico (Findley et al. 1975, Hubbard et al. 1983, Hoffmeister 1986, Frey et al. 1995, Frey 2005).

Voles are difficult to identify based on morphological features, and erroneous records of M. montanus have been reported in the American Southwest. Microtus montanus does not occur in northeastern New Mexico or southwestern Colorado as originally reported by Dalquest (1975) and Mellott and Choate (1984), and subsequently by (Hall 1981). Several authors have corrected these misidentifications (e.g., Hubbard et al. 1983, Finley et al. 1986,
Mellott et al. 1987, Frey 2004), yet the erroneous records continue to be reported (e.g., Hoffmann and Koeppl 1985, Sera and Early 2003). A specimen of M. montanus was reported from the Zuni Mountains in western New Mexico (Bailey 1900, 1931, Hall and Cockrum 1953, Hall and Kelson 1959). However, Anderson (1954) questioned its identity as either $M$. montanus or Microtus mexicanus, while Anderson (1959) and Frey (2005) referred it to Microtus longicaudus. Anderson (1959) reassigned a specimen from the Jemez Mountains to $M$. longicaudus that Bailey (1931) originally identified as M. montanus.

Two subspecies of M. montanus have been described in the American Southwest, including M. m. arizonensis Bailey 1898 from Springerville, Apache County, Arizona, and M. m. fusus Hall 1938 from 2.5 miles east of Cochetopa Pass, Saguache County, Colorado. Anderson (1959) studied geographic variation within $M$. montanus by utilizing univariate statistics of 3 external and 7 cranial measurements and qualitative descriptions of pelage. His analysis included 2 populations from the White Mountains in Arizona and a group that combined specimens from the Jemez and southern San Juan mountains in New Mexico and southern Colorado. Anderson (1959) concluded that all specimens from northern New Mexico (Jemez and San Juan mountains) should be assigned

${ }^{1}$ Museum of Southwestern Biology and Department of Biology, University of New Mexico, Albuquerque, NM 87131.

${ }^{2}$ Present address: Department of Fish, Wildlife, and Conservation Ecology, and The Vertebrate Museum, Department of Biology, New Mexico State University, Box 30003, Campus Box 4901, Las Cruces, NM 88003. E-mail: jfrey@nmsu.edu 


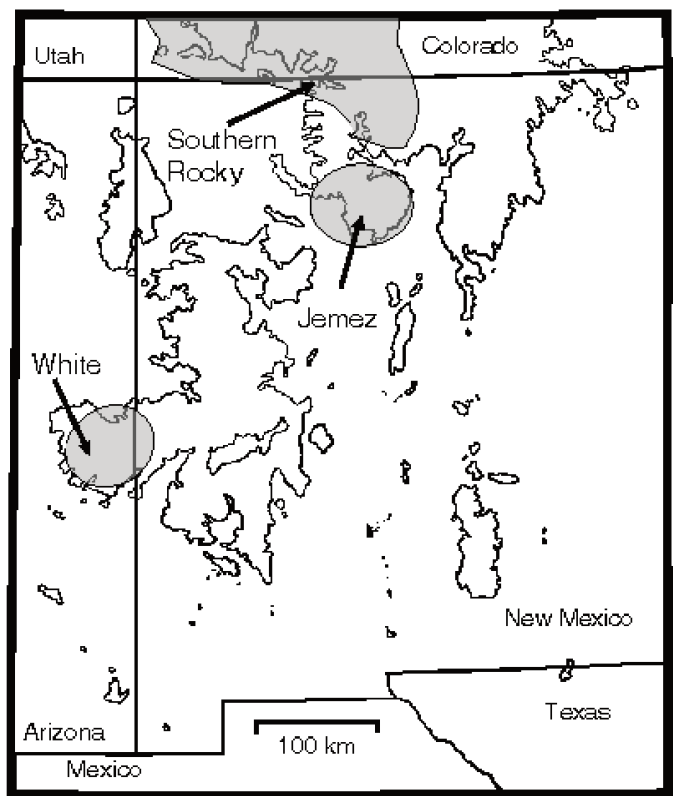

Fig. 1. Distribution of $M$. montanus in the southwestern USA (shading) and names of mountain ranges mentioned in the text. Thin lines are 2134-m contour intervals.

to M. m. fusus, while specimens from the White Mountains were referable to $M . m$. arizonensis. However, combining specimens from the Jemez Mountains with those from the San Juan Mountains may have obscured the variation between those populations. Earlier taxonomic treatments referred specimens from the Jemez Mountains to M. m. arizonensis (Bailey 1931, Hall and Cockrum 1953). Further, Findley and Jones (1962) subsequently found that each of the 3 southwestern populations differed significantly in size, with size increasing from north to south, although no taxonomic conclusions were made. Current subspecies treatment of southwestern populations generally follows the arrangement of Anderson (1959), wherein M. m. arizonensis is restricted to the White Mountains and adjacent areas of Arizona and New Mexico, while M. m. fusus is applied to the Jemez Mountains and San Juan Mountains in New Mexico north to the valleys of the Colorado, Roaring Fork, and Arkansas rivers in Colorado (Anderson 1959, Armstrong 1972, Hall 1981, Sera and Early 2003, Frey 2004).

Genetic characteristics of southwestern populations of $M$. montanus are poorly known and have not been taxonomically informative. No chromosomal variation was found in G-bands and nucleolus organizer regions in specimens from the White and Jemez mountains (Judd et al. 1980). Moore and Janecek (1990) found no allozyme variation at 25 presumptive loci for 6 specimens of $M$. montanus from the Jemez Mountains. Thus, the purpose of this study was to describe genetic characteristics of southwestern populations of $M$. montanus and to assess current subspecies taxonomy of these populations.

\section{Methods}

The analysis of allozyme variation included a total of $54 \mathrm{M}$. montanus collected from the White Mountains in Arizona, Jemez Mountains in New Mexico, and San Juan Range of the Southern Rocky Mountains in Colorado (see Appendix for specimens examined). Specimens of the M. mexicanus species group, which also occurs in montane habitats in the American Southwest, were utilized for comparisons. Dental and allozyme data have indicated a close relationship among these species (Chaline 1980, Moore and Janecek 1990; but see Conroy and Cook 2000 for a contrasting view based on mitochondrial cytochrome b gene sequences). Frey and LaRue (1993) and Frey et al. (2002) regarded specimens in the $M$. mexicanus group from the USA as specifically distinct from those in Mexico, with those from the USA referred to as the Mogollon vole, M. mogollonensis, and those from Mexico referred to as the Mexican vole, M. mexicanus. Thus, specimens of both M. mogollonensis and M. mexicanus were included for comparisons.

Heart, liver, and kidney tissue samples were taken from each animal and frozen in liquid nitrogen. Tissues were maintained at $-80{ }^{\circ} \mathrm{C}$ until analyzed by horizontal starch-gel electrophoresis. Tissues were homogenized (heart and kidney processed together) and applied to $11 \%$ starch gels. Procedures, buffer types, and biochemical stains follow a modification of Selander et al. (1971), Harris and Hopkinson (1976), and Murphy et al. (1990). In multiplelocus systems, the isozyme migrating most anodally was designated as " 1 " while peptidase loci were designated for their substrate. Alleles were identified alphabetically beginning with the most anodally migrating allele, designated as "A."

A total of 21 presumptive loci were analyzed; buffer systems, tissues and presumptive 
loci (enzyme abbreviations and Enzyme Commission numbers in parentheses) examined were as follows: $\mathrm{LiOH} \mathrm{pH} 8.1$ buffer (liver); general protein-1, -2 (GP-1, -2), superoxide dismutase (SOD; EC 1.15.1.1), glycyl-L-leucine peptidase (PEP-gl; EC 3.4.13.11), L-leucylglycylglycine peptidase (PEP-lgg; EC 3.4.11.4), esterase-1, -2 (EST-1, -2; nonspecific). Phosphate $\mathrm{pH} 6.7$ buffer (liver); L-iditol dehydrogenase (IDDH; EC 1.1.1.14), aspartate aminotransferase-1, -2 (AAT-1, -2; EC 2.6.1.1), glycerol-3-phosphate dehydrogenase (G3PDH; EC 1.1.1.8). Tris-citrate $\mathrm{pH} 8.0$ buffer (liver); glutamate dehydrogenase (GTDH; EC 1.4.1.2), glucose-6-phosphate dehydrogenase (G6PDH; EC 1.1.1.49), alcohol dehydrogenase (ADH; EC 1.1.1.1). Tris-citrate $\mathrm{pH} 6.7$ buffer (kidney and heart): isocitrate dehydrogenase-1, -2 (IDH1, -2; EC 1.1.1.42), L-lactate dehydrogenase-1, -2 (LDH-1, -2; EC 1.1.1.27), malate dehydrogenase-1, -2 (MDH-1, -2; EC 1.1.1.37), malate dehydrogenase NADP+ (MDHP; EC 1.1.1.40).

A table of allele frequencies was constructed for all loci. The program BIOSYS-1 (Swofford and Selander 1981) was used for calculations of the allozyme data. Estimates of genetic variation for each population were determined including polymorphism $(P$, the proportion of loci that are polymorphic for which the most common allele has a frequency $<0.95$ ), allelic diversity $(A$, the mean number of alleles per locus), observed direct-count heterozygosity $(H$-obs, the mean proportion of all loci observed that were heterozygous per individual), and expected heterozygosity ( $\mathrm{H}-\mathrm{W}$, the mean expected Hardy-Weinberg heterozygosity). Significant deviations from Hardy-Weinberg proportions were calculated using the Levene correction for small sample size in chi-square analyses. Coefficients of Rogers' (1972) genetic similarity were calculated from allele frequency data for all loci and all possible pairs of populations. Phenetic relationships among the populations were summarized as a phenogram obtained by subjecting the Rogers' similarity matrix to the UPGMA cluster analysis option of BIOSYS-1.

A smaller sample of specimens was analyzed for mtDNA restriction-site variation (Appendix). DNA was extracted from liver, muscle, or pellets recovered after homogenation of tissues for protein electrophoresis. Tissues were digested with Proteinase K, 20\% SDS, and STE for 1 hour at $55{ }^{\circ} \mathrm{C}$. DNA was purified using successive extractions with $5 \mathrm{M} \mathrm{NaCl}$, phenol:chloroform:isoamyl alcohol (24:24:1), and methylene chloride: isoamyl alcohol (24:1), and was precipitated with ethanol and resuspended in TE buffer (Politov et al. 2004).

An approximately 1200-base-pair (bp) region of the mtDNA control region (D-loop) was amplified from purified DNA by automated polymerase chain reaction (PCR; originally described by Saiki et al. 1988). Amplification was accomplished utilizing primers (L15926 and H00651) and a modification of procedures described by Kocher et al. (1989). The PCR reactions were performed in $100 \mu \mathrm{L}$ volumes using $2 \mu \mathrm{L}$ DNA, $5 \mu \mathrm{L}$ of each $10 \mu \mathrm{M}$ primer, $5 \mu \mathrm{L}$ of $10 \mathrm{mM}$ dNTP, $10 \mu \mathrm{L}$ buffer (Kocher et al. 1989), $37 \mu \mathrm{L} 25 \mathrm{mM} \mathrm{MgCl}_{2}, 5$ units Taq polymerase (Cetus brand), and $\mathrm{H}_{2} \mathrm{O}$. PCR was carried out in 35 cycles of denaturation at 94 ${ }^{\circ} \mathrm{C}$ for 1 minute, annealing at $50{ }^{\circ} \mathrm{C}$ for 1 minute, and extension at $72^{\circ} \mathrm{C}$ for 2 minutes.

Each amplified DNA sample was digested with 10 restriction enzymes, including $A l u \mathrm{I}$, BamHI, BfaI, DpnII, EcoRI, HaeIII, HhaI, HindIII, HinfI, and PstI. Each digest consisted of $10 \mu \mathrm{L}$ amplified DNA, 3 units enzyme, 3 $\mu \mathrm{L}$ appropriate $10 \mathrm{X}$ enzyme buffer, $3 \mu \mathrm{L}$ bovine serum albumin if needed, and $\mathrm{H}_{2} \mathrm{O}$ to a final $30 \mu \mathrm{L}$ volume. Samples were digested for at least 4 hours at $37^{\circ} \mathrm{C}$ and then run on an agarose gel (2.5\%-3.0\%) made with TBE buffer and to which ethidium bromide was added. Fragments were visualized under ultraviolet light and fragment sizes were determined by comparison with DNA size standards.

\section{RESULTS}

Nine allozyme loci were monomorphic across all samples including AAT-2, GP-1, IDH2, LDH-1, MDH-1, MDH-2, MDHP, PEP-gl, and SOD. Twelve loci were polymorphic (Table 1). Three loci (ADH, EST-2, IDDH) were fixed for different alleles among populations of the 3 species. Southwestern populations of $M$. montanus were fixed for unique alleles at 4 loci (ADH, EST-2, GP-2, IDDH), the population of $M$. mexicanus was fixed for unique alleles at 5 loci (ADH, EST-1, EST-2, G6PDH, IDDH), and the population of $M$. mogollonensis was fixed for unique alleles at 3 loci (ADH, EST-2, IDDH). The populations of M. mexicanus and M. mogollonensis were fixed for different alleles at 5 loci (ADH, EST-1, EST-2, G6PDH, 
TABLE 1. Allele frequencies for variable allozyme loci and estimates of genetic variability for southwestern populations of Microtus montanus, M. mogollonensis, and M. mexicanus.

\begin{tabular}{|c|c|c|c|c|c|c|}
\hline \multirow[b]{2}{*}{$\begin{array}{l}\text { Locus and } \\
\text { genetic variation }\end{array}$} & \multirow[b]{2}{*}{ Allele } & \multicolumn{3}{|c|}{ M. montanus } & \multirow[b]{2}{*}{$\begin{array}{c}\text { Microtus } \\
\text { mogollonensis } \\
\quad(n=7)\end{array}$} & \multirow[b]{2}{*}{$\begin{array}{c}\text { Microtus } \\
\text { mexicanus } \\
(n=10)\end{array}$} \\
\hline & & $\begin{array}{c}\text { Rocky, CO } \\
(n=20)\end{array}$ & $\begin{array}{c}\text { Jemez, NM } \\
\quad(n=14)\end{array}$ & $\begin{array}{c}\text { White, AZ } \\
(n=20)\end{array}$ & & \\
\hline \multirow[t]{2}{*}{ AAT-1 } & A & 1 & 1 & 0.9 & 1 & 1 \\
\hline & B & 0 & 0 & 0.1 & 0 & 0 \\
\hline \multirow[t]{3}{*}{ ADH } & A & 1 & 1 & 1 & 0 & 0 \\
\hline & B & 0 & 0 & 0 & 1 & 0 \\
\hline & $\mathrm{C}$ & 0 & 0 & 0 & 0 & 1 \\
\hline \multirow[t]{2}{*}{ EST-1 } & A & 1 & 1 & 1 & 1 & 0 \\
\hline & B & 0 & 0 & 0 & 0 & 1 \\
\hline \multirow[t]{3}{*}{ EST-2 } & A & 0 & 0 & 0 & 0 & 1 \\
\hline & B & 0 & 0 & 0 & 1 & 0 \\
\hline & $\mathrm{C}$ & 1 & 1 & 1 & 0 & 0 \\
\hline \multirow[t]{2}{*}{ GDH } & A & 1 & 0.929 & 0.95 & 1 & 0.9 \\
\hline & B & 0 & 0.071 & 0.05 & 0 & 0.1 \\
\hline \multirow[t]{2}{*}{ GP-2 } & A & 1 & 1 & 1 & 0 & 0 \\
\hline & B & 0 & 0 & 0 & 1 & 1 \\
\hline \multirow[t]{2}{*}{ G3PDH } & A & 1 & 1 & 0.925 & 1 & 1 \\
\hline & B & 0 & 0 & 0.075 & 0 & 0 \\
\hline \multirow{2}{*}{ G6PDH } & A & 0 & 0 & 0 & 0 & 1 \\
\hline & B & 1 & 1 & 1 & 1 & 0 \\
\hline \multirow[t]{2}{*}{ IDH-1 } & A & $0.972 \mathrm{a}$ & 1 & 1 & 1 & 1 \\
\hline & B & 0.028 & 0 & 0 & 0 & 0 \\
\hline \multirow[t]{2}{*}{ LDH-2 } & A & 1 & 1 & 1 & 0.714 & 1 \\
\hline & B & 0 & 0 & 0 & 0.286 & 0 \\
\hline \multirow[t]{2}{*}{ PEP-lgg } & A & 0.95 & 1 & 0.95 & 1 & 1 \\
\hline & B & 0.05 & 0 & 0.05 & 0 & 0 \\
\hline \multirow[t]{3}{*}{ IDDH } & A & 0 & 0 & 0 & 1 & 0 \\
\hline & B & 1 & 1 & 1 & 0 & 0 \\
\hline & $\mathrm{C}$ & 0 & 0 & 0 & 0 & 1 \\
\hline$P$ & 4.8 & 4.8 & 19.0 & 4.8 & 4.8 & \\
\hline \multirow[t]{2}{*}{$A$} & mean & 1.1 & 1.0 & 1.2 & 1.0 & 1.0 \\
\hline & $s_{\bar{x}}$ & 0.1 & 0 & 0.1 & 0 & 0 \\
\hline \multirow[t]{2}{*}{$H$-obs } & mean & 0.003 & 0 & 0.017 & 0 & 0 \\
\hline & $s_{\bar{x}}$ & 0.003 & 0 & 0.012 & 0 & 0 \\
\hline \multirow[t]{2}{*}{$\mathrm{H}-\mathrm{W}$} & mean & 0.007 & 0.007 & 0.025 & 0.021 & 0.009 \\
\hline & $s_{\bar{x}}$ & 0.005 & 0.007 & 0.012 & 0.021 & 0.009 \\
\hline
\end{tabular}

IDDH). Among populations of M. montanus, most estimates of genetic variation were notably higher in the White Mountains population (Table 1).

Within populations of M. montanus, 2 loci exhibited significant deviations from HardyWeinberg proportions including PEP-lgg in the Southern Rocky $\left(\chi^{2}=39.0, P<0.001\right)$ and White $\left(\chi^{2}=39.0, P<0.001\right)$ mountains and GTDH in the Jemez $\left(\chi^{2}=27.0, P<0.001\right)$ and White $\left(\chi^{2}=39.0, P<0.001\right)$ mountains. The populations of $M$. mogollonensis and $M$. mexicanus each exhibited significant deviations from Hardy-Weinberg proportions at 1 locus each, including LDH-2 $\left(\chi^{2}=8.9, P=0.003\right)$ and GDH-1 $\left(\chi^{2}=19.1, P<0.001\right)$, respectively. In all cases there was a heterozygote deficiency (coefficient of heterozygosity deficiency $=-1.00)$.

Coefficients of Rogers' (1972) genetic similarity between all paired populations ranged from 0.701 between the population of $M$. mexicanus and the population of M. montanus in the White Mountains to 0.993 between populations of $M$. montanus from the Southern Rocky and Jemez mountains (Table 2). The population of $M$. mogollonensis was more similar to southwestern populations of M. montanus 
TABLE 2. Coefficients of Rogers' (1972) genetic similarity based on allozyme data for all pairwise combinations of southwestern populations of Microtus montanus, M. mogollonensis, and M. mexicanus.

\begin{tabular}{lccccc}
\hline & \multicolumn{5}{c}{ M. montanus } \\
\cline { 2 - 3 } & Colorado & New Mexico & Arizona & M. mogollonensis & M. mexicanus \\
\hline Rocky & $\overline{-}$ & & & \\
Jemez & 0.993 & $\overline{-}$ & - & \\
White & 0.988 & 0.988 & 0.783 & & \\
M. mogollonensis & 0.792 & 0.713 & 0.701 & 0.744 & - \\
M. mexicanus & 0.706 & & & \\
\hline
\end{tabular}

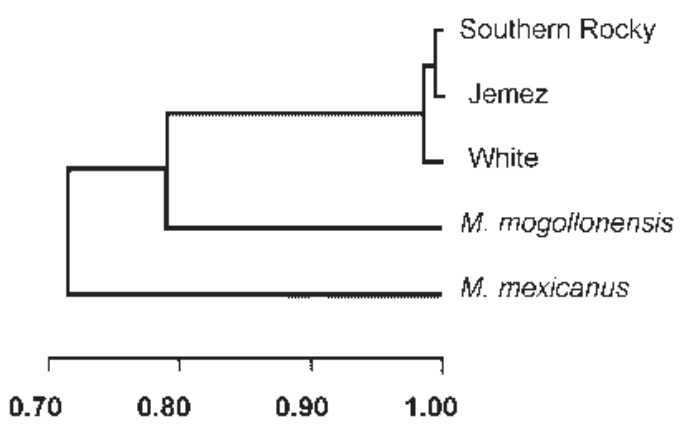

Fig. 2. UPGMA phenogram based on Rogers' (1972) genetic similarity values for 3 southwestern populations of M. montanus, Microtus mogollonensis, and M. mexicanus. Cophenetic correlation coefficient $=0.996$.

than it was to the population of M. mexicanus, and the population of $M$. mexicanus was the least similar compared with the other populations (Table 2, Fig. 2). Among southwestern populations of $M$. montanus, populations from the Southern Rocky and Jemez mountains were most similar (Fig. 2).

No restriction sites were found within the 1200-bp segment of the mtDNA control region in any of the specimens for 6 restriction enzymes, including BamHI, $B f a \mathrm{I}, E c o$ RI, HindIII, HinfI, and PstI. All individuals of M. mogollonensis had a unique restriction fragment pattern for $D p n I I$, while some individuals of all 3 populations of $M$. montanus had a unique restriction fragment pattern for HhaI. All individuals from the White Mountains population of $M$. montanus had unique restriction fragment patterns for AluI, DpnII, and HaeIII. There were 5 haplotypes: haplotype $a$ was found in the population of M. mexicanus and in the populations of $M$. montanus from the Southern Rocky and Jemez mountains; haplotype $b$ was found in the populations of $M$. montanus from the Southern Rocky and Jemez mountains; haplotypes $c$ and $d$ were found in the population of M. montanus from the White Mountains; and haplotype $d$ was found in all individuals of M. mogollonensis (Table 3).

\section{Discussion}

In general, estimates of polymorphism and observed heterozygosity were lower than typically found in other mammals, including other species of Microtus (15\% and 5\% respectively; Selander and Johnson 1973, Gaines 1985). However, polymorphism in the White Mountains population of $M$. montanus was higher than the average for mammals. Ditto and Frey (2007) found that for several montane small mammal species in the American Southwest, measures of genetic variation exhibited significant positive relationships with the area of montane coniferous forest habitat and significant negative relationships with the isolation of coniferous forest habitat "islands" from the Rocky Mountain "mainland" habitat area. In contrast to these general patterns, the smallest, most isolated population of $M$. montanus, the White Mountains population, had higher estimates of genetic variation compared to other populations (Table 4).

Although Findley and Jones (1962) found a significant difference in size between M. montanus from the San Juan and Jemez mountains, little genetic differentiation was found between these populations. However, results of the allozyme and mtDNA analyses indicate that within southwestern populations of $M$. montanus, considerable genetic differentiation has occurred in the population from the White Mountains. The White Mountains population had 2 unique allozyme alleles and unique restriction sites for 3 restriction enzymes within the mtDNA control region that were not found in other populations of southwestern M. montanus, M. mexicanus, or M. mogollonensis. This pattern of differentiation is consistent with the 
TABLE 3. Frequency of variable restriction fragments and haplotypes within 1200 base pairs of the mtDNA control region in southwestern populations of Microtus montanus, M. mogollonensis, and M. mexicanus.

\begin{tabular}{|c|c|c|c|c|c|c|}
\hline \multirow[b]{2}{*}{$\begin{array}{l}\text { Restriction } \\
\text { enzyme }\end{array}$} & \multirow[b]{2}{*}{$\begin{array}{l}\text { Fragment } \\
\text { size }\end{array}$} & \multicolumn{3}{|c|}{ M. montanus } & \multirow[b]{2}{*}{$\begin{array}{l}\text { M. mogollonensis } \\
\quad(n=11)\end{array}$} & \multirow[b]{2}{*}{$\begin{array}{l}\text { M. mexicanus } \\
(n=2)\end{array}$} \\
\hline & & $\begin{array}{l}\text { Rocky } \\
(n=3)\end{array}$ & $\begin{array}{l}\text { Jemez } \\
(n=5)\end{array}$ & $\begin{array}{l}\text { White } \\
(n=5)\end{array}$ & & \\
\hline \multirow[t]{2}{*}{$A l u \mathrm{I}$} & 1200 & 1 & 1 & 0 & 1 & 1 \\
\hline & $650 / 550$ & 0 & 0 & 1 & 0 & 0 \\
\hline \multirow[t]{3}{*}{ DpnII } & 1200 & 1 & 1 & 0 & 0 & 1 \\
\hline & $925 / 275$ & 0 & 0 & 0 & 1 & 0 \\
\hline & $800 / 400$ & 0 & 0 & 1 & 0 & 0 \\
\hline \multirow[t]{2}{*}{ HaeIII } & $725 / 475$ & 1 & 1 & 0 & 1 & 1 \\
\hline & $475 / 400 / 250$ & 0 & 0 & 1 & 0 & 0 \\
\hline \multirow[t]{2}{*}{ HhaI } & 1200 & 0.5 & 0.8 & 0.8 & 1 & 1 \\
\hline & $850 / 350$ & 0.5 & 0.2 & 0.2 & 0 & 0 \\
\hline Haplotypes & & $a, b$ & $a, b$ & $\mathrm{c}, \mathrm{d}$ & $\mathrm{e}$ & $\mathrm{a}$ \\
\hline
\end{tabular}

TABLE 4. Ecogeographic characteristics of montane habitat islands with populations of Microtus montanus in the American Southwest.

\begin{tabular}{lccc}
\hline $\begin{array}{l}\text { Mountain } \\
\text { range }\end{array}$ & $\begin{array}{c}\text { Area of mesic coniferous } \\
\text { forest habitat }\left(\mathrm{km}^{2}\right)\end{array}$ & $\begin{array}{c}\text { Isolation from the Rocky } \\
\text { Mountain mainland }(\mathrm{km})\end{array}$ & $\begin{array}{c}\text { Habitat of the } \\
\text { intervening barrierc }\end{array}$ \\
\hline Rocky & 60,152 & 0 & - \\
Jemez & 913 & 45 & 386 \\
White & 670 & coniferous woodland \\
shortgrass steppe
\end{tabular}

Data were taken from Patterson (1984).

bIsolation was the shortest straight-line distance between mesic coniferous forest patches measured on the map by Küchler (1964),

cHabitat was determined from the map by Küchler (1964).

species biogeography. The White Mountains population is separated from the Southern Rocky Mountains population by a further distance than is the population from the Jemez Mountains (Table 4). In addition, the White Mountains are also isolated by lower-elevation vegetation zones, which are increasingly unsuitable habitat for these voles. The White Mountains are isolated from the Rocky Mountains by a barrier of grama (Bouteloua)-galleta (Hilaria) steppe, while the Jemez Mountains are isolated by a barrier of juniper (Juniperus)-pinyon (Pinus) woodland (Küchler 1964; Table 4). For montane forest mammals, grasslands have been considered relatively harsh barriers to dispersal, while woodlands have been considered filters to contemporary dispersal (Lomolino et al. 1989). The extreme isolation of the White Mountains population has allowed for considerable genetic differentiation of this population.

Both the allozyme and mtDNA data revealed considerable divergence of the White Mountains population relative to the other southwestern populations of $M$. montanus. This pattern of genetic divergence was concordant with the biogeography of the region. Thus, the evidence supports recognition of the
White Mountains population as a distinct subspecies, M. m. arizonensis, while the populations from the Jemez Mountains and Southern Rocky Mountains are referable to M. m. fuscus. Finally, both the allozyme and mtDNA data supported Frey and LaRue (1993) in recognizing M. mogollonensis as distinct from M. mexicanus. Frey and LaRue (1993) based this decision on both karyotypic (Judd 1980, Modi 1987) and morphologic (Frey 1989) data. Results of this study indicate that populations of these species are fixed for different alleles at 5 allozyme loci and have different haplotypes for the mtDNA control region. In addition, the overall level of allozyme similarity between the populations of the 2 species was consistent with species-level differences among 9 species of Microtus, based on a similar suit of markers (Moore and Janecek 1990).

\section{ACKNOWLEDGMENTS}

I am grateful to L. Marcello Zalles for assistance in the laboratory. Special thanks go to E.L. Braun, B.C. Frey, B.J. Frey, J.D. Frey, P.J. Glass, and D.W. Moore for help with specimen collection and to the Museum of Southwestern Biology, University of New Mexico, for the loan 
of specimens. E.L. Braun and J. Robbins provided advice on aspects of the DNA analyses. J.H. Brown, D.O. Natvig, E.O. Wiley, T.L. Yates, and R. Van den Bushe provided comments on a previous version of this paper. Portions of this research were partially supported by NSF-HRD-9253051 and by grants from the University of New Mexico Student Research Allocations Committee; University of New Mexico, Department of Biology, Graduate Research Allocations Committee; the Albert R. and Alma E. Schadle Fellowship in Mammalogy provided by the Buffalo Foundation and the American Society of Mammalogists; and Sigma Xi.

\section{Literature Cited}

ANDERSON, S. 1954. Subspeciation in the meadow mouse, Microtus montanus, in Wyoming and Colorado. University of Kansas Publications, Museum of Natural History 7:489-506.

1959. Distribution, variation, and relationships of the montane vole, Microtus montanus. University of Kansas Publications, Museum of Natural History 9:415-511.

Armstrong, D.M. 1972. Distribution of mammals in Colorado. Monograph of the Museum of Natural History, University of Kansas 3:1-415.

BaILey, V. 1898. Descriptions of eleven new species and subspecies of voles. Proceedings of the Biological Society of Washington 12:85-90.

1900. Revision of American voles of the genus Microtus. North American Fauna 17:1-88.

. 1931 (=1932). Mammals of New Mexico. North American Fauna 53:1-412.

Chaline, J. 1980. Essai de filiation des campagnols et des lemmings (Arvicolidae, Rodentia) en zone Holarctique d'après la morphologie dentaire. Pages 375-382 in Palaeovertebrata: Mémoire Jubilaire Hommage R. Lavocat.

Conroy, C.J., AND J.A. Cook. 2000. Molecular systematics of a Holarctic rodent (Microtus: Muridae). Journal of Mammalogy 81:344-359.

DaLquest, W.W. 1975. The montane vole in northeastern New Mexico and adjacent Colorado. Southwestern Naturalist 20:138-139.

DitTo, A.M., And J.K. Frey. 2007. Effects of ecogeographic variables on genetic variation in montane mammals: implications for conservation in a global warming scenario. Journal of Biogeography 34: $1136-1149$

Findley, J.S., A.H. Harris, D.E. Wilson, and C. Jones. 1975. Mammals of New Mexico. University of New Mexico Press, Albuquerque.

Findley, J.S., AND C.J. JoNES. 1962. Distribution and variation of voles of the genus Microtus in New Mexico and adjacent areas. Journal of Mammalogy 43:154-166.

Finley, R.B., JR., J.R. Choate, and D.F. Hoffmeister. 1986. Distribution and habitats of voles in southeastern Colorado and northeastern New Mexico. Southwestern Naturalist 31:263-266.
FrEY, J.K. 1989. Morphologic variation in the Mexican vole (Microtus mexicanus). Master's thesis, Emporia State University, Emporia, KS.

2004. Taxonomy and distribution of the mammals of New Mexico: an annotated checklist. Museum of Texas Tech University, Occasional Papers 240:1-32. 2005. Status of the Arizona montane vole (Microtus montanus arizonensis) in New Mexico. Final report to New Mexico Department of Game and Fish, Santa Fe.

Frey, J.K., J.H. Fraga, and F.C. Bermudez. 1995. A new locality of the montane vole (Microtus montanus arizonensis) in New Mexico. Southwestern Naturalist 40:421-422.

Frey, J.K., and C.T. LaRue. 1993. Notes on the distribution of the Mogollon vole (Microtus mogollonensis) in New Mexico and Arizona. Southwestern Naturalist 38:176-178.

Frey, J.K., J.J. Root, C.A. Jones, C.H. Calisher, and B.J. BEATy. 2002. New records of the Mogollon vole, Microtus mogollonensis (Mearns 1890), in southwestern Colorado. Western North American Naturalist 62:120-123.

HaLl, E.R. 1938. Notes on the meadow mice Microtus montanus and $M$. nanus with description of a new subspecies from Colorado. Proceedings of the Biological Society of Washington 51:131-134.

. 1981. The mammals of North America. 2nd edition. John Wiley \& Sons, New York. 1181 pp.

Hall, E.R., AND E.L. Cockrum. 1953. A synopsis of the North American microtine rodents. University of Kansas Publications, Museum of Natural History 5:373-498.

GaINES, M.S. 1985. Genetics. Pages 845-883 in R.H. Tamarin, editor, Biology of New World Microtus. American Society of Mammalogists, Special Publication $8.893 \mathrm{pp}$.

HaLl, E.R., AND K.R. KeLson. 1959. The mammals of North America. 1st edition. Ronald Press Company, New York. 1083 pp.

Harris, H., and D.A. Hopkinson. 1976. Handbook of enzyme electrophoresis in human genetics. American Elsevier Publishing Company, Inc., New York. $573 \mathrm{pp}$.

Hoffmann, R.S., and J.W. KoEppl. 1985. Zoogeography. Pages 84-115 in R.H. Tamarin, editor, Biology of New World Microtus. Special Publication, American Society of Mammalogists 8.

HoffmeisTER, D.F. 1986. Mammals of Arizona. University of Arizona Press and Arizona Game and Fish Department, Tucson. 602 pp.

Hubbard, J.P., D.S. Thaeler, JR., and C.G. SchmitT. 1983. Notes on voles (Microtus, Family Cricetidae) in New Mexico. Nemouria: Occasional Papers of the Delaware Museum of Natural History 28:1-8.

JUDD, S.R. 1980. Observations of the chromosome variation in Microtus mexicanus (Rodentia: Microtinae). Mammalian Chromosome Newsletter 21:110-113.

Judd, S.R., S.P. Cross, and S. PathaK. 1980. Non-Robertsonian chromosomal variation in Microtus montanus. Journal of Mammalogy 61:109-113.

Kocher, T.D., W.K. Thomas, A. Meyer, S.V. Edwards, S. Paabo, F.X. Villablanca, and A.C. Wilson. 1989. Dynamics of mitochondrial DNA evolution in animals: amplification and sequencing with conserved primers. Proceedings of the National Academy of Science 86:6196-6200. 
KüCHLER, A.W. 1964. Potential natural vegetation of the conterminous United States, 1:3,168,000 [map]. Special Publication of the American Geographical Society.

Lomolino, M.V., J.H. Brown, AND R. Davis. 1989. Island biogeography of montane forest mammals in the American Southwest. Ecology 70:180-194.

Mellott, R.S., and J.R. Choate. 1984. Sciurus aberti and Microtus montanus on foothills of the Culebra Range in southern Colorado. Southwestern Naturalist 29:135-137.

Mellott, R.S., J.R. Choate, and C. Loeffletr. 1987. Mammals of Spanish Peaks State Wildlife Area, Colorado. Fort Hays Studies, 3rd series [science] 9:1-30.

Modi, W.S. 1987. Phylogenetic analyses of chromosomal banding patterns among the Nearctic Arvicolidae (Mammalia: Rodentia). Systematic Zoology 36: 109-136.

Moore, D.W., ANd L.L. Janecek. 1990. Genic relationships among North American Microtus (Mammalia: Rodentia). Annals of the Carnegie Museum 59: 249-259.

Murphy, R.W., J.W. Sites, JR., D.G. Buth, and C.H. Haufler. 1990. Proteins I: isozyme electrophoresis. Pages 45-1206 in D.M. Hillis and C. Moritz, editors, Molecular systematics. Sinauer Associates, Inc., Sunderland, MA. 588 pp.

Patterson, B.D. 1984. Mammalian extinction and biogeography in the southern Rocky Mountains. Pages 247-293 in M.H. Nitecki, editor, Extinctions. University of Chicago Press, Chicago, IL. 354 pp.
Politov, D.V., J.W. Bickham, J.C. Patton. 2004. Molecular phylogeography of Palearctic and Nearctic ciscoes. Annales Zoologici Fennici 41:13-23.

Rogers, J.S. 1972. Measures of genetic similarity and genetic distance. Studies in Genetics. VII. University of Texas Publications 7213:145-153.

Saiki, R.K., D.H. Gelfand, S. Stoffel, S.J. Scharf, R. Higuchi, G.T. Horn, K.B. Muldis, H.A. Erlich. 1988. Primer-directed enzymatic amplification of DNA with thermostable DNA polymerase. Science 239:487-491.

SELANDER, R.K., AND W.E. Johnson. 1973. Genetic variation among vertebrate species. Annual Review of Ecology and Systematics 4:75-91.

Selander, R.K., M.H. Smith, S.Y. Yang, W.E. Johnson, AND G.B. GENTRY. 1971. Biochemical polymorphism and systematics in the genus Peromyscus. I. Variation in the oldfield mouse (Peromyscus polionotus). Studies in Genetics. VI. University of Texas Publications 7103:49-90.

SERa, W.W., and C.N. Early. 2003. Microtus montanus. Mammalian Species 716:1-10.

Swofford, D.L., AND R.B. SELANDER. 1981. BIOSYS-1, a computer program for the analysis of allelic variation in genetics. Department of Genetics and Development, University of Illinois, Urbana. 65 pp.

Received 28 February 2008 Accepted 2 December 2008

APPENDIX. Collection localities for specimens of Microtus montanus, Microtus mogollonensis, and Microtus mexicanus utilized in the analysis of allozyme variation. Specimens indicated with an asterisk (*) were utilized in the analyses for both allozyme and mtDNA variations, while specimens indicated with a plus $(+)$ were utilized only for mtDNA variation. The Museum of Southwestern Biology (MSB), University of New Mexico tissue catalog numbers (NK numbers) for each specimen are in parentheses; standard voucher specimens are housed in the MSB.

Microtus mexicanus

MEXICO: MeXico: 17.5 km S, 7 km W Toluca, Nevado de Toluca (9634, 9635, 9636, 9637, 9638, 9639, 9644, 9645, 9654, 9655, 9656+, 9657+).

Microtus mogollonensis

USA: Arizona: Apache Co.-Apache National Forest, White Mountains, Sheep Camp Spring, T8N, R26E, S 1/2 Sec 25 (20077, 20078, 20088); Apache National Forest, White Mountains, Sheep Spring, T8N, R26E, S 1/2 Sec 26 (20075, 20076, 20090, 20091). Coconino Co.-Kaibab National Forest, south rim Grand Canyon, West Skinner Tank, T29N, R4E, NW 1/4 Sec 7 (20016+, 20020+, 20021+); Coconino National Forest, Mogollon Rim, Lee Johnson Spring, T12N, R9E, NE 1/4 Sec 12 (20055+, 20056+). Mohave Co.-Hualapai Mountains, Camp Levi Levi, T20N, R15W, SW 1/4 of NE 1/4 Sec 30, elevation $7600 \mathrm{ft}(20958+)$; Hualapai Mountains, Frees Wash, T20N, R15W, SW 1/4 of SW 1/4 Sec 16, elevation $7400 \mathrm{ft}(20970+)$. Hualapai Indian Reservation, $1.5 \mathrm{mi}$ south and $0.25 \mathrm{mi}$ west of Oak Tank, T30N, R8W, Sec 18 SE $1 / 4$ of SE 1/4, elevation $6480 \mathrm{ft}(20963+)$. Yavapai Co._-Bradshaw Mountains, Goodwin, T21N, R1W, NW 1/4 of NW 1/4 Sec 28, elevation $5600 \mathrm{ft}(20950+, 20951+, 20952+)$.

Microtus montanus

USA: ARIzona: Apache Co.-Apache National Forest, White Mountains, Sheep Camp Spring, T8N, R26E, S 1/2 Sec 25 (20070*, 20071*, NK 20072*, 20073*, 20083*, 20094); Apache National Forest, White Mountains, Sheep Spring, T8N, R26E, S 1/2 Sec 26 (20089, 20092); 15.9 mi S, 10.1 mi E Springerville, Escudilla Mountains, Terry Flat, T6N, R31E, NW 1/4 Sec 19 (20105, 20106, 20107, 20114, 20128, 20130); 4 mi S, 16 mi W Alpine, West Fork Campground (1933, 1936, 9809, 9811, 9857, 9859). Colorado: Archuleta Co.- $0.6 \mathrm{mi}$ S junction U.S. 160 and Colorado 151, T34N, R4W, E 1/2 Sec 10 (20264*, 20265, 20266*, 20267*, 20268, 20269, 20270, 20271, 20272, 20274, 20275). Gunnison Co.Commissary Campground, T50N, R4W, S 1/2 Sec 19 (20255, 20258, 20259, 20260, 20262). Pitkin Co.—2.0 mi SE Aspen, T10S, R84W, Sec 20 (20244A, 20244B, 20245, 20246). New MexiCO: Sandoval Co.-0.6 mi NE jct. NM Hwy. 44 and NM Hwy. 96, 3.25 mi N, 1.25 mi W Cuba, T21N, R1W, SE 1/4 Sec 6 (20789*); Jemez Mountains, 2 mi S, 5 mi E Cuba, Horseshoe Spring, T20N, R1E, NE 1/4 Sec 6 (20790*, 20791*); Jemez Mountains, Guadalupe Canyon, Llano Loco Spring, T18N, R1E, SW 1/4 Sec 12 (20792*); 3 mi N, 9.5 mi E Jemez Springs (1704, 1705, 1713*, 1717); 3 mi N, 10.5 mi E Jemez Springs (1725, 1726, 1727, 1728); 15 mi N, 2 mi E Jemez Springs (4768, 4769). 